\title{
Prinsip Kesantunan dan Prinsip Kerja Sama dalam Komunikasi Ulasan Produk pada Marketplace
}

\author{
Didik Suharijadi \\ Jurusan Sastra Indonesia, Fakultas Ilmu Budaya, Universitas \\ Jemberdidikparavisi@gmail.com
}

Diterima 7 Desember 2017/Disetujui 7 Januari 2018

\begin{abstract}
Abtract
This article discusses how to apply principles of cooperation and principles of politeness in communication between sellers and buyers in online business. The research object is specialized in online business through the marketplace and more specifically on product reviews. Marketplace is a platform or online system that mediates transactions between sellers and buyers. Marketplace has the tools of communicating between seller and buyer consisting of product description page, product discussion page, product review page, and personal message page. Of the four communication facilities are only product description pages, product discussion pages and product reviews pages that can be accessed by the public. Private message pages can only be accessed by the account owner who is communicating with other account owners. Product reviews are an important facility as most potential buyers see product reviews before buying. Product descriptions and product discussions are also important to note, but more product reviews show evidence of the quality of product and services. The reality is that not all marketplace users look at the pragmatic principles of communicating in product reviews. Specializing in product reviews is also based on frequent conflicts in product reviews between the seller and the buyer at this communication facility. The sample of this research is Tokopedia marketplace. Samples are selected because that marketplace is one of the largest online business media in Indonesia.
\end{abstract}

Keywords: pragmatics, business communication, marketplace, online

business, cooperative principles, principles of courtesy, positive face, negative face

\section{Pendahuluan}

Bisnis daring telah menjadi trend saat ini. Perilaku konsumen telah berubah dari aktivitas berbelanja secara fisik ke berbelanja secara virtual melalui telefon cerdas.Berbelanja secara daring memberikan banyak kemudahan.Pembeli dapat menjelajah gerai para penjual tanpa terkendala ruang dan waktu. Selain itu platform lapak daring (marketplace) juga meyediakan berbagai alat bantu seperti alat pengurut (sort) dan alat penyaring (filter). Konsumen dapat mengurutkan barang berdasarkan harga maupun jumlah penjualan.Konsumen juga dapat menyaring barang berdasarkan rating, lokasi, rentang harga, kategori, dan fasilitas kurir.

Bisnis melalui media daring juga mengubah perilaku para pebisnis.Kemudahan yang disediakan oleh pengembang platform menyebabkan bermunculan banyak pebisnis baru (Sumber).Lapak daring tidak memerlukan modal tempat dan perizinan. Pebisnis cukup membuka registrasi akun kemudian mengisi slot produk dengan foto dan deskripsi produk. Pebisnis juga tidak dikenai pajak penjualan.Fenomena inilah yang menyebabkan pelaku bisnis konvensionalbahkan yang telah mapan seperti Matahari Departemen 
Store, perlahan memilih beralih ke media daring karena pendapatan merekaterus menurun

(http://ekonomi.kompas.com/read/2017/09/15/175813026/dua-gerai-ditutupbisnis-matahari-mulai-meredup, diakses pada 1 Desember 2017).

Kemudahan-kemudahan dalam bisnis melalui media daring menyebabkan muncul para pebisnis dari beragam latar belakang.Keragaman latar belakang para pebisnis tampak dari perilaku berbahasa dalam lapak daring mereka.Tidak semua bahasa pebisnis memenuhi prinsip kerja sama dan prinsip sopan santun. Realitas berbahasa yang demikian terjadi karenaderajat kesantunan yang dinyatakan oleh seorang penutur akan ditentukan oleh situasi berlangsungnya pertuturan atau bergantung pada konteks, sehingga derajat kesantunan tersebut akan berbeda pada setiap latar sosial pertuturan (Leech,1993). Pendekatan pragmatik dapat mengukur pemahaman penggunaan bahasa pebisnis sebagaimana yang tampak pada ulasan produk.

Komunikasi bisnis akan berjalan lancar apabila kedua pihak memenuhi prinsip kerja sama dan prinsip sopan santun. Akibat dari kelemahan dalam menerapkan prinsip pragmatik, pebisnis dapat memperoleh reputasi negatif.Sebaliknya, kemampuan menerapkan prinsip pragmatikdapat meningkatkan reputasi positif. Reputasi adalah fasilitas yang disediakan oleh pengembang marketplace untuk menimbulkan proses seleksi alamiah. Lapak yang banyak memperoleh reputasi positif akan dipercaya oleh calon pelanggan, dan akhirnya akan berdampak pada keberlangsungan bisnisnya. Lapak yang banyak menerima reputasi negatif akan sepi pembeli dan perlahan tidak aktif.Sibarani (2004) mengemukakan pendapat yang sesuai dengan realitas dalam bisnis daring ini.Lebih rinci Sibarani menyebutkan bahwa kesantunan berbahasa sangat penting dipelajari dan diterapkan karena (1) kesopansantunan seseorang dinilai dari bahasanya yang santun atau dari "budi bahasanya"e; (2) bahasa yang santun akan memperlancar penyampaian pesan dalam berkomunikasi; (3) bahasa yang kurang santun sering menyakitkan perasan orang lain sehingga tidak jarang menjadi sumber konflik; dan (4) masyarakat Indonesia secara historis dianggap sebagai masyarakat yang santun dan baik budi bahasanya sehingga hal itu penting dipertahankan.Berdasar latar belakang tersebut maka teori-teori yang digunakan dalam analisis ini adalah teori-teoriprinsip kerja sama dan prinsip sopan santunsebagaimana dirinci dalam sub-sub berikut.

\subsection{Prinsip Kerja Sama}

Dalam komunikasi, umumnya seorang penutur mengartikulasikan ujaran dengan maksud untuk mengkomunikasikan sesuatu kepada lawan tuturnya, dan berharap lawan tuturnya dapat memahami apa yang hendak dikomunikasikan. Demi mencapai tujuan tersebut penutur berusaha agar tuturannya selalu relevan dengan konteks, jelas, mudah dipahami, padat dan ringkas (concise), serta konsisten pada persoalan (straight forward), sehingga tidak menghabiskan waktu lawan bicaranya (Wijana, 1996). Sejalan dengan pendapat Wijana tersebut Grice dan Austin (dalam Leech, 1993) menjabarkan prinsip kerja sama dalam empat 
maksim (conversational maxim), yakni maksim kuantitas (maxim of quantity), maksim kualitas (maxim of quality), maksim relevansi (maxim of relevance), dan maksim pelaksanaan (maxim of manner).

Maksim kuantitas menghendaki setiap peserta pertuturan memberikan kontribusi yang secukupnya atau sebanyak yang dibutuhkan oleh lawan bicaranya.Maksim kualitas mewajibkan setiap peserta percakapan mengatakan hal yang sebenarnya.Kontribusi peserta percakapan hendaknya didasarkan pada buktibukti yang memadai.Apabila patuh pada prinsip ini, jangan pernah mengatakan sesuatu yang diyakini bahwa itu kurang benar atau tidak benar.Maksim relevansi mengharuskan setiap peserta percakapan memberikan kontribusi yang relevan dengan masalah pembicaraan.Maksim pelaksanaan mengharuskan setiap peserta percakapan berbicara secara langsung, tidak kabur, tidak taksa, tidak berlebihan, dan runtut.

\subsection{Prinsip Sopan Santun}

Kesantunan berbahasa dalam setiap budaya penerapannya berbeda-beda, namun ada kriteria-kriteria universal yang yang harus dipatuhi oleh para pelibat agar tercipta komunikasi yang efektif, terhindar dari kesalahpahaman, dan tidak menyinggung perasaan orang lain. Leech (1993) merumuskan kriteria-kriteria kesantunan yang terdiri atas enam maksim, yaitu maksim kearifan, maksim kedermawanan, maksim pujian, maksim kerendahan hati, maksim kesepakatan, dan maksim simpati.

Maksim kearifan menggariskan setiap peserta pertuturan untuk meminimalkan kerugian orang lain atau memaksimalkan keuntungan bagi orang lain. Leech (dalam Wijana, 1996)mengatakan bahwa semakin panjang tuturan seseorang semakin besar pula keinginan orang itu untuk bersikap sopan kepada lawan bicaranya. Demikian pula tuturan yang diutarakan secara tidak langsung lazimnya lebih sopan dibandingkan dengan tuturan yang diutarakan secara langsung. Maksim kemurahan menuntut setiap peserta pertuturan untuk memaksimalkan rasa hormat kepada orang lain, dan meminimalkan rasa tidak hormat kepada orang lain. Maksim penerimaan mengharuskan setiap peserta tuturan untuk memaksimalkan kerugian bagi diri sendiri, dan meminimalkan keuntungan diri sendiri. Maksim kerendahan hati berpusat pada diri sendiri. Maksim ini menuntut setiap peserta pertuturan untuk memaksimalkan ketidakhormatan pada diri sendiri, dan meminimalkan rasa hormat pada diri sendiri. Maksim kecocokan menggariskan setiap penutur dan lawan tutur untuk memaksimalkan kecocokan diantara mereka, dan meminimalkan ketidakcocokan di antara mereka. Maksim kesimpatian mengharuskan setiap peserta pertuturan untuk memaksimalkan rasa simpati, dan meminimalkan rasa antipati kepada lawan tutur. Jika lawan tutur mendapatkan kesuksesan atau kebahagiaan, penutur wajib memberikan ucapan selamat. Bila lawan tutur mendapat kesusahan, atau musibah penutur layak berduka, atau mengutarakan bela sungkawa sebagai tanda kesimpatian Brown dan Levinson (dalam Chaer, 2010) membagi kesantunan atas "muka negatif" dan "muka positif". Muka negatif mengacu pada citra diri yang menyebabkan orang lain merasa tidak nyaman atau terganggu. 
Muka positif adalah citra diri yang menimbulkan perasaan nyaman lawan tutur.

Robin Lakoff (1973) menyatakan kesantunan dikembangkan oleh masyarakat guna mengurangi friksi dalam interasi pribadi. Lakoff menetapkan tiga kaidah yang harus dipatuhi untuk menerapkan kesantunan, yaitu: formalitas (formality), ketidaktegasan (hesitancy), dan kesamaan atau kesekawanan (equality atau cemeraderie).

Fraser (dalam Gunarwan, 1994) mendasarkan kesantunan berbahasa bukan pada kaidah-kaidah, melainkan atas dasar strategi.Fraser membedakan kesantunan (politeness) dari penghormatan (deference).Kesantunan adalah properti yang diasosiasikan dengan tuturan. Kesantunan adalah pendapat si lawan tutur, bahwa si penutur tidak melampaui hak-haknya atau tidak mengingkari dalam memenuhi kewajibannya. Sedangkan penghormatan adalah bagian dari aktivitas yang berfungsi sebagai sarana simbolis untuk menyatakan penghargaan secara regular.

Pranowo (2009) memberikan pedoman bagaimana berbicara secara santun.Menurut Pranowo suatu tuturan akan terasa santun apabila memperhatikan hal-hal berikut:

1. Menjaga suasana perasaan lawan tutur sehingga dia berkenan bertutur dengan kita;

2. mempertemukan perasaan kita (penutur) dengan perasaan lawan tutur sehingga isi tuturan sama-sama dikehendaki karena sama-sama diinginkan;

3. menjaga agar tuturan dapat diterima oleh lawan tutur karena dia sedang berkenan di hati;

4. menjaga agar dalam pertuturan terlihat ketidakmampuan penutur di hadapan lawan tutur;

5. menjaga agar dalam tuturan selalu terlihat posisi lawan tutur selalu berada pada posisi yang lebih jauh;

6. menjaga agar dalam tuturan selalu terlihatbahwa apa yang dikatakan kepada lawan tutur juga dirasakan oleh penutur.

Tuturan, penutur dan lawan tutur dalam artikel ini dikaitkan dengan konteks komunikasi yang menyertai. Konteks tersebut meliputi tanggapan lawan tutur dan penggunaan simbol bintang sebagai penanda reputasi. Analisis diharapkan dapat menjawab permasalahan sejauh mana prinsip kerja sama dan prinsip sopan santun diterapkan dalam komunikasi antara penjual dan pembeli di ulasan produk dalam bisnis daring.

\subsection{Implikatur}

Implikatur adalah implikasi pragmatis yang terdapat di dalam percakapan. Implikatur timbul karena terjadi pelanggaran prinsip percakapan. Implikatur percakapan terjadi karena adanya kenyataan bahwa sebuah ujaran yang mempunyai implikasi di balik tuturan yang tampak. Jadi implikatur 
bukanlahbagian dari tuturan dan bukan pula merupakan konsekuensi yang harus ada dari tuturan itu (Gunawan, 2007:52).

\section{Metode}

Penelitian ini akan menganalisis data berupa komunikasi tertulis yang terjadi antara penjual dan pembeli di laman ulasan produk. Data diperoleh dengan metode simak dengan teknik sadap dan teknik libat cakap (Sudaryanto, 1993:133137). Teknik sadap untuk diterapkan untuk mendapatkan data tuturan penjual dan pembeli. Teknik libat cakap diterapkan agar data-data yang diperoleh melalui teknik sadap lebih valid. Untuk menunjang kedua teknik tersebut peneliti membuat akun di Tokopedia. Peneliti juga aktif sebagai penjual dengan membuat toko online bernama Bhinneka Sport sejak bulan Juli 2014. Dengan cara ini peneliti dapat menjadi pengamat pasif (penyadap) dan juga dapat menjadi pengamat aktif (pelibat) sebagai pembeli maupun sebagai penjual. Tokopedia dipilih sebagai sampel karena Tokopedia termasuk marketplace terbesar di Indonesia (https://id.techinasia.com/marketplace-online-terbesar-indonesiabelanja, diakses pada 12 Oktober 2016).

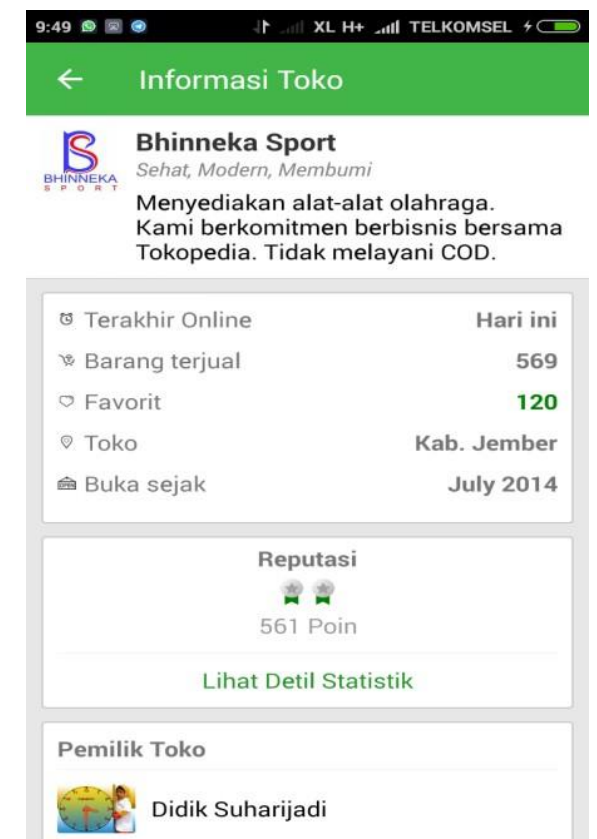

Data 1. Peneliti berpartisipasi dengan membuka toko sejak Juli 2014

Data yang dipandang sesuai dengan keperluan analisis kemudian didokumentasikan denganteknik rekam layar (screenshoot) untuk disimpan menjadi data berupa file gambar berformat JPG.Analisi dilakukan dengan metode padan pragmatis dengan teknik dasar hubung banding (Sudaryanto, 1993:25 - 26). Peneliti akan melakukan interpretasi terhadap fenomena berbahasa yang telah terdata kemudian memberikan pembanding dari data yang lain atau menyodorkan alternatif bentuk bahasa yang diciptakan oleh peneliti berdasarkan pengalaman peneliti sebagai penjual. Metode padan pragmatik juga 
menghubungbandingkantuturan dengan konteks yang menyertainya. Konteks tersebut meliputi segala informasi yang tampil di laman ulasan produk yaitu tanda bintang yang menunjukkan rating (penilaian oleh penjual), tanda pin reputasi (yang menunjukkan kuantitas transaksi penjual), informasi waktu posting ulasan pembeli, dan informasi waktu posting tanggapan penjual. Rating dengan 1 bintang artinya sangat buruk, dua bintang artinya buruk, tiga bintang artinya standard atau lumayan, empat bintang artinya baik, lima bintang artinya sangat baik. Pin reputasi satu buah warna perak artinya penjualan telah menjapai 250 hingga 500 barang. Setiap pin perak menandai kelipatan 500. Misal, dua pin perak menandai penjualan 501 hingga 1000 barang.

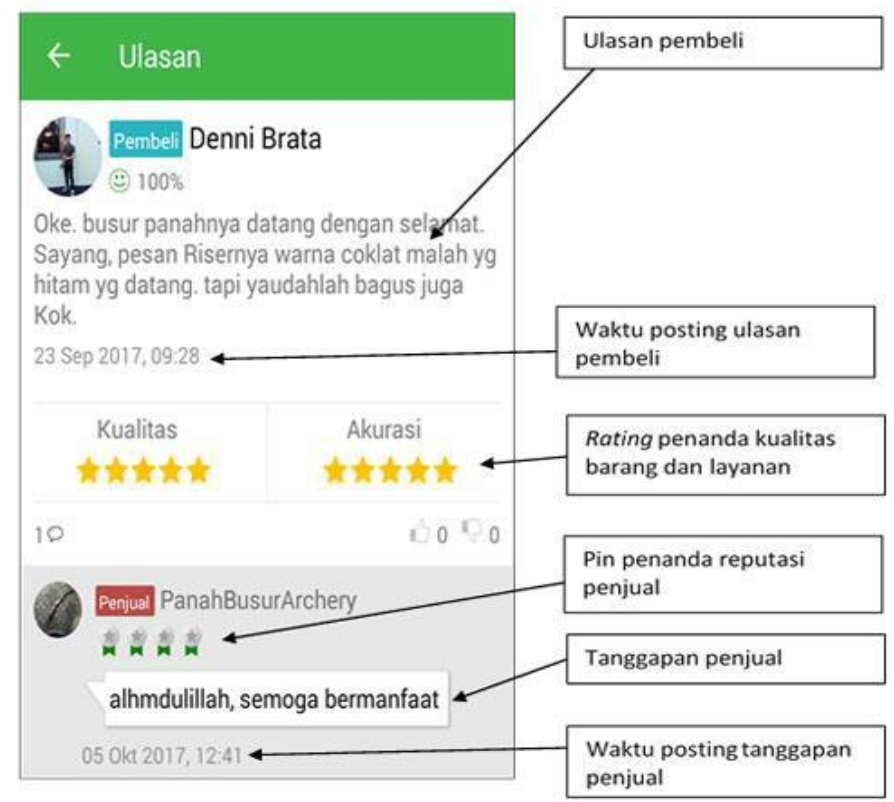

Data 2. Konteks yang menyertai tuturan

Data 2 menunjukkan pembeli bernama Denni Brata memberikan ulasan disertai rating lima bintang yang menandakan bahwa dia menilai kualitas layanan sangat bagus dan kualitas barang juga sangat bagus. Bintang lima menunjukkan bahwa pembeli memberi penilaian (rating) sangat baik. Penjual memberi tanggapan. Pin di bawah nama toko menunjukkan bahwa penjual memiliki reputasi penjualan cukup banyak ditandai dengan empat pin. Perbandingan antara waktu posting ulasan oleh pembeli (23 Serptember 2017) dan waktu posting tanggapan oleh penjual (05 Oktober 2017) menunjukkan tanggapan yang lambat dari penjual.

\section{Pembahasan}

Halaman ulasan adalah fasilitas yang disediakan di marketplace untuk memberi kesempatan pembeli memberikan penilaian.Penilaian meliputi kualitas barang, kesesuaian antara deskripsi produk dengan kenyataan produk, harga, dan kualitas layanan yang diberikan oleh penjual. Ulasan positif biasanya diikuti dengan pemberian ratingbaik berupa tanda bintang sebanyak empat hingga lima buah. Empat bintang berarti baik. Lima bintang berarti sangat baik. Ulasan negatif 
biasanya diikuti dengan pemberian rating buruk berupa tanda bintang satu hingga tiga buah.Satu bintang berarti sangat buruk. Dua bintang berarti buruk. Tiga bintang berarti biasa atau tidak cukup baik. Berikut akan diulas data-data terkait ulasan positif dan ulasan negatif.

\subsection{Prinsip Pragmatik dalam Ulasan Positif}

Ulasan positif diberikan karena pembeli berniat memberi kesaksian tanpa menjatuhkan reputasi penjual. Ulasan positif diberikan karena pembeli merasa puas, atau kurang kuas tetapi disampaikan dengan mengutamakan prinsip kerja sama dan atau prinsip sopan santun. Ulasan positif didasari oleh kualitas barang dan kualitas layanan. Tanggapan atas ulasan positif ini sangat penting. Penjual biasanya menanggapi ulasan positif dengan tanggapan positif pulasehingga transaksi berakhir dengan kesan positif. Kesan positif ini diharapkan dapat memotivasi pembeli untuk berbelanja lagi atau menjadi pelanggan setia.Kesan positif juga diharapkan menjadi daya tarik bagi calon pembeli.Berikut adalah data komunikasi ulasan positif.

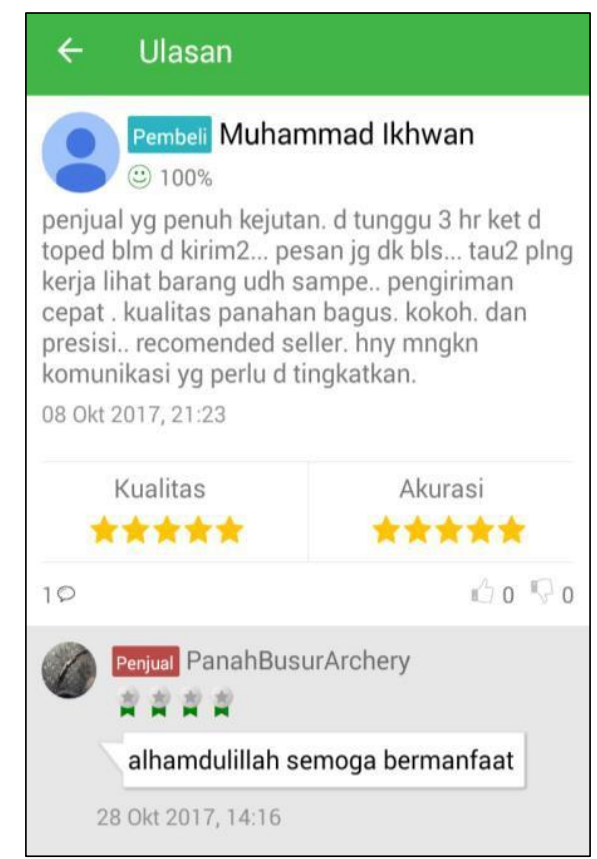

Data 3.

Pembeli pada ulasan di atas menyampaikan ulasan dengan mematuhi prinsip kerja sama dengan mengoptimalkan hampir semua maksim. Maksim kuantitas dipenuhi dengan menyampaikan secara detail informasi transaksinya mulai dari informasi bahwa barang sudah sampai, pengiriman cepat, kualitas barang bagus, dan menilai pembeli terpercaya (recomendedseller). Maksim kualitas juga dipenuhi dengan tuturan "kokoh", "presisi". Tuturan pembeli tentang hal-hal positif terkait barang yang diterima membuktikan bahwa pembeli telah meneliti dan mengujinya sebelum memberi ulasan. Pemenuhan maksim kualitas dikuatkan dengan pemberian rating lima bintang yang menandakan bahwa barang 
dan layanan yang ia terima sangat bagus. Maksim relevansi dipenuhi oleh penjual dengan tidak menyertakan topik-topik yang tidak berkaitan dengan transaksi.

Hanya maksim carayang sengaja dilanggar oleh pembeli pada data 3 . Pembeli seolah ingin memuji penjual dengan tuturan "penjual yang penuh kejutan" tetapi tuturan berikutnya menunjukkan kekecewaan sebagaimana diungkapkan dengan "pesan juga tdk dibalas".Sebenarnya ia ingin menyampaikan bahwa pembeli kurang responsif dalam berkomunikasi. Pembeli dapat menyampaikan keluhan tersebut secara lebih lugas, tetapi ia sengaja melanggar maksim cara untuk kepentingan mengedepankan prinsip sopan santun. Di akhir ulasan pembeli menyampaikan kritik halus dengan tuturan "hny mngk komunikasi yg perlu ditingkatkan".Tuturan ini membuktikan bahwa pembeli berusaha memenuhi maksim kebijaksanaan, dan maksim kemurahan.

Penjual dalam konteks data 3 memberikan respon yang mengutamakan prinsip sopan santun khususnya maksim kerendahan hati.Tuturan "alhamdulillah" menekankan bahwa segala penilaian positif atas dirinya semata-mata karena kebesaran Allah.Selain itu penjual juga berusaha memenuhi maksim kebijaksanaan dengan mengungkapkan "semoga bermanfaat".Penjual berharap dapat memberikan keuntungan sebesar-besarnya.

Dari sisi pelaksanaan prinsip kerja sama penjual telah mengabaikan keluhan dan saran pembeli tentang kelambatan respon komunikasi. Tidak ada ucapan terima kasih, tidak ada permintaan maaf, tidak ada pula tanggapan atas keluhan dan saran.Padahal rentang waktu antara posting ulasan pembeli (23 Serptember 2017) dan waktu posting tanggapan oleh penjual (05 Oktober 2017) menunjukkan juga membuktikan bahwa penjual memang cenderung lambat dalam merespon komunikasi.Dengan demikian penjual telah melanggar prinsip kerja sama khususnya maksim relevansi dan maksim kuantitas.

Kecenderungan perilaku komunikasi yang demikian ternyata berulang.Penjual cenderung mengesampingkan maksim relevansi dan maksim kuantitas sebagaimana tampak pada data 4 berikut. 


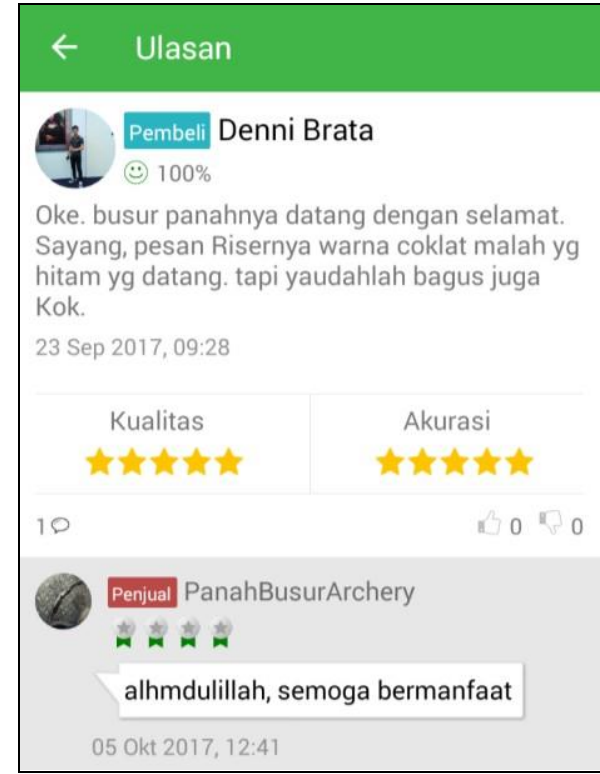

Data 4

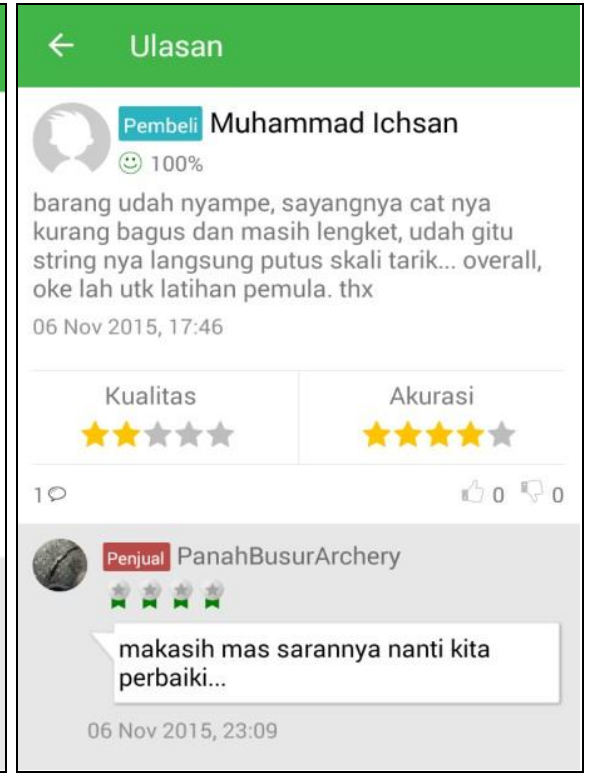

Data 5

Pembeli pada data 4 berusaha mengutamakan prinsip kerja sama khususnya maksim kuantitas dengan mengatakan bahwa barang yang dia order telah sampai dengan selamat. Pembeli juga memenuhi maksim kualitas dengan mengatakan yang sebenarnya bahwa barang bagus.Pembeli juga berusaha menerapkan prinsip sopan santun dengan memenuhi maksim penerimaan dan kecocokan. Walaupun menyatakan kekecewaan karena barang yang ia terima tidak sesuai dengan yang ia pesan, pebeli menyatakan menerima dengan tuturan "yaudahlah". Maksim kecocokan diutamakan oleh pembeli dengan tuturan "bagus juga kok".Berdasarkan konteks tersebut, pantas dicurigai bahwa rating lima bintang (khususnya di bagian akurasi) bukanlah wujud pemenuhan maksim kualitas, melainkan wujud pemenuhan maksim kemurahan dan atau maksim penerimaan. Penjual mengulang pelanggaran yang sama dengan data sebelumnya, yaitu tidak memberi respon atas ketidakpuasan pembeli. Berbeda penjual pada data 4, penjual pada data 5 mampu menjaga prinsip kerja sama dan prinsip sopan santun.

Tuturan penjual pada data 5 menampakkan pemenuhan prinsip kerja sama dan prinsip sopan santun. Tuturan "makasih mas sarannya nanti kita perbaiki..." memenuhi maksim kuantitas, relevansi, dan cara. Dengan tanggapan yang ringkas, mengena/relevan, dan lugas mengimplikasikan bahwa penjual menerima saran, berniat memperbaiki, dan berharap pembeli tidak jera bertransaksi dengannya.

Dalam ulasan juga terdapat penghentian komunikasi satu pihak yang ditandai dengan ketiadaan respon oleh penjual. Fenomena tersebut dapat dilihat pada data 6 dan 7 berikut. 


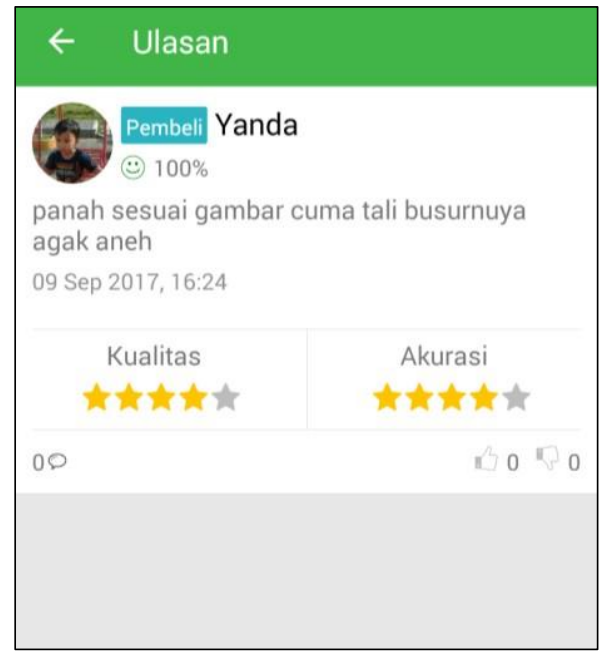

Data 6

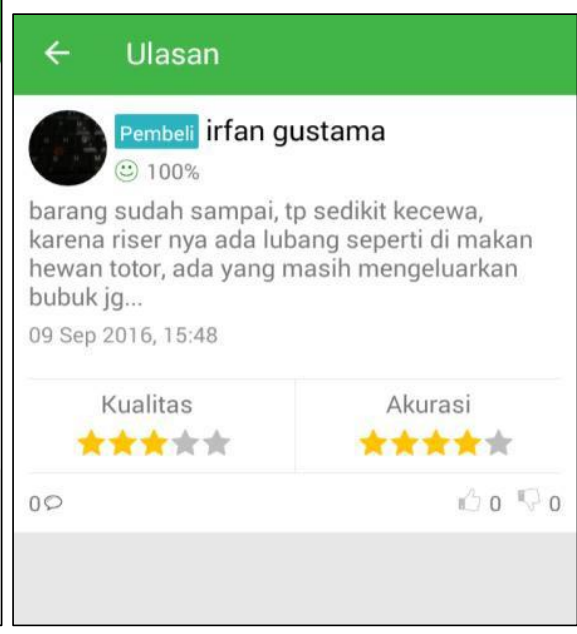

Data 7

Pembeli pada data 6 dan 7 telah menunjukkan itikad untuk menjunjung prinsip sopan santun dan prinsip kerja sama. Tuturan "panah sesuai" dan diikuti pemberian rating bintang empat menunjukkan bahwa pembeli telah jujur menilai barang.Konteks demikian menunjukkan bahwa pembeli telah memenuhi maksim kualitas.Pembeli juga berupaya berusaha memenuhi prinsip sopan santun maksim kebijaksanaan dengan menggunakan tuturan "agak aneh".Mirip dengan pembeli pada data 6, pembeli pada data 7 menggunakan tuturan "sedikit kecewa" untuk mengurangi penilaian negatif pada pembeli. Upaya memenuhi maksim kebijaksanaan pada kedua data tersebut juga didukung dengan pemberian rating bintang empat yang menandai bahwa penjual mengapresiasi baik barang dan layanan yang ia terima.Kedua ulasan tersebut tidak direspon oleh penjual. Dengan demikian penjual telah melanggar prinsip kerja sama dan prinsip sopan santun.

Transaksi yang baik seharusnya berakhir dengan kepuasan pembeli maupun penjual.Ulasan atas transaksi yang berakhir memuaskan umumnya menampakkan pemenuhan prinsip pragmatik sebagaimana tampak pada data 8berikut. 


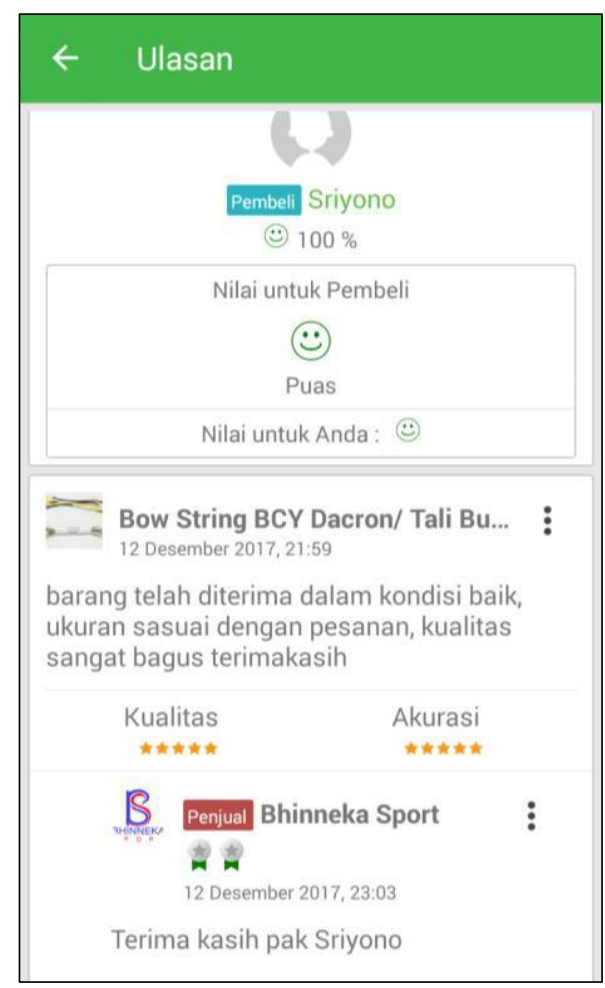

Data 8

Pembeli pada data 8menjunjung prinsip kerjasama dan prinsip sopan santun. Kalimat yang disampaikan ringkas, jelas, mengena, dan santun. Dalam kalimat ulasan yang singkat pembeli telah memberikan informasi tentang barang telah diterima, kondisi barang baik, barang yang diterima sesuai dengan yang dipesan, kualtas barang bagus, dan ucapan terima kasih sebagai tanda simpati. Ulasan diikuti dengan pemberian rating lima bintang menandakan bahwa pembeli menganggap kualitas barang maupun layanan sangat baik.

Penjual pada data 8 juga memenjunjung prinsip sopan santun. Dengan menyampaikan terima kasih dan menyebut nama pembeli penjual telah memenuhi maksim kerendahan hati dan maksim kemurahan. Singkatnya rentang waktu antara posting ulasan (12 Desember 2017, pukul 21:59) dengan posting tanggapan (12 Desember 2017, pukul 23:02) membuktikan bahwa penjual telah berusaha memberikan layanan sebaik-baiknya dengan merespon komunikasi secepatcepatnya.

Karakteristik pembeli bermacam-macam. Ada pembeli yang suka mengutamakan prinsip kerja sama dan prinsip sopan santun seperti pembeli pada data 10, ada juga yang hanya mengutamakan prinsip kerja sama seperti pada data 9 berikut. 


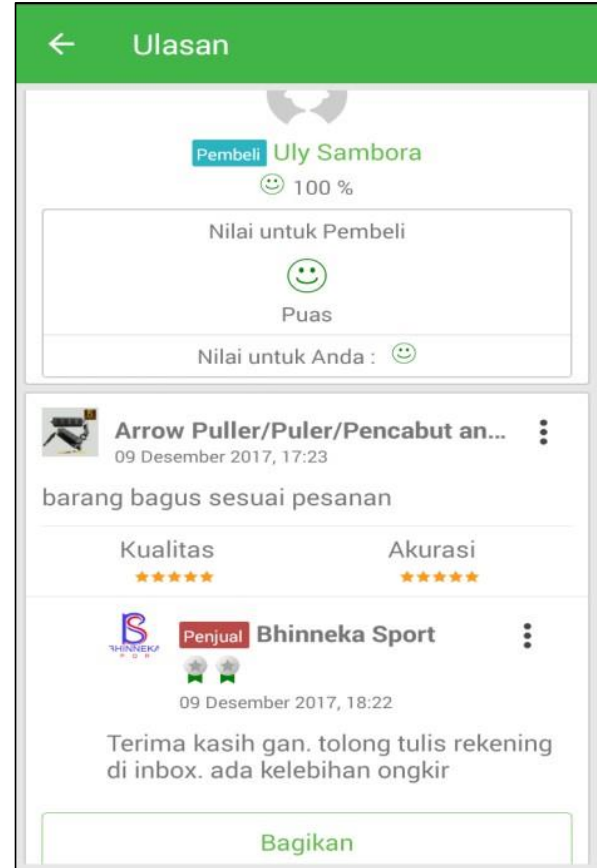

Data 9

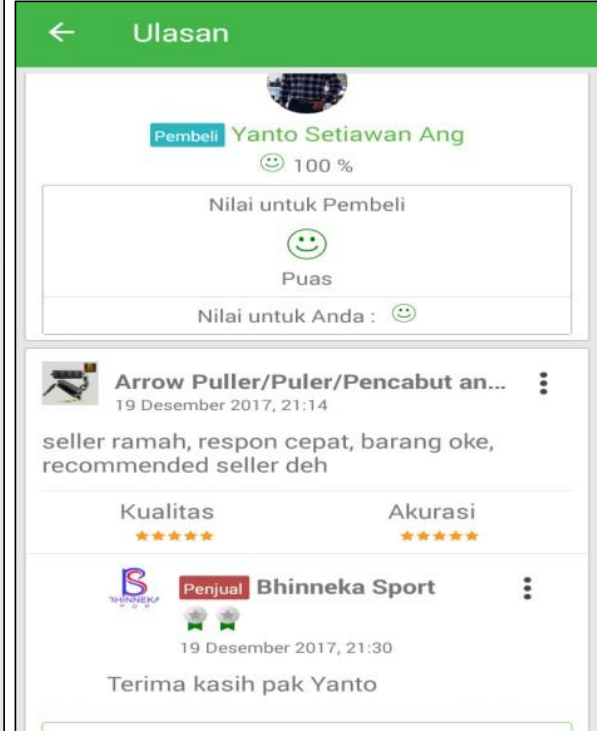

Data 10

Pembeli pada data 9 cenderung menyukai berkomunikasi dengan ringkas dan jelas. Dengan kalimat "barang bagus sesuai pesanan" penjual telah memenuhi maksim-maksim yang mendukung prinsip kerja sama. Tidak perlu mengungkapkan pujian seperti yang dilakukan oleh pembeli pada data 10, ulasan pembeli pada data 9 yang diikuti rating lima bintang tersebut sudah menginformasikan bahwa penjual tergolong recomended seller.

Penjual pada data 9 menerapkan prinsip sopan santun dan prinsip kerja sama. Tuturan "terima kasih", dan "tolong" merupakan upaya pemenuhan maksim kemurahan dan kerendahan hati. Tuturan "ada kelebihan ongkir" menunjukkan bahwa penjual juga menjunjung prinsip kerja sama khususnya maksim kualitas.

Pelanggaran maksim kuantitas oleh penjual juga terjadi pada ulasan produk.Berikut data yang menunjukkan fenomena tersebut.

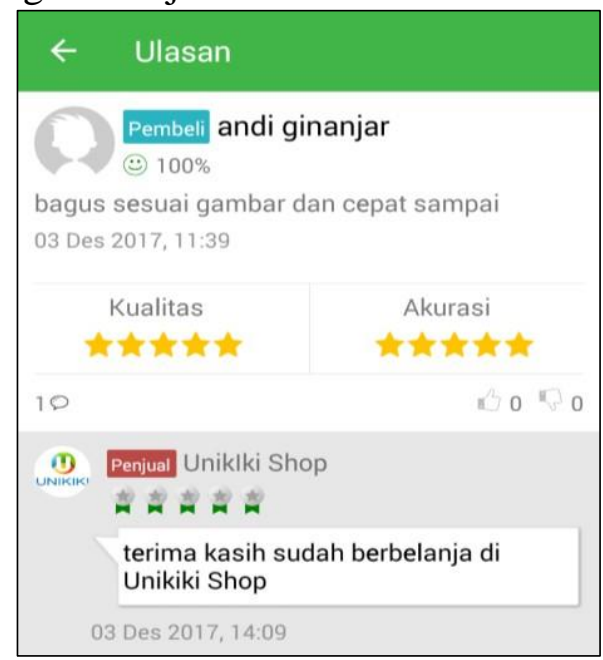

Data 11 
Pada data 11 pembeli menyampaikan ulasan positif dengan disertai rating bintang lima yang menandai bahwa barang maupun layanan yang ia terima sangat bagus. Pembeli menanggapi dengan tuturan "terima kasih sudah berbelanja di Uniiki Shop". Tanggapan pembeli melanggar maksim kuantitas karena menyampaikan informasi secara berlebihan. Ulasan adalah kesaksian pembeli yang diberikan setelah membeli. Ulasan tidak mungkin diberikan olah person yang belum berbelanja. Jadi, tuturan "sudah beanja di Uniiki Shop" adalah informasi yang mubazir. Seharusnya pembeli menanggapi dengan tuturan "Terima kasih, kami menunggu order berikutnya". Serupa dengan fenomena pada data 11, data 12 dan 13 juga menampilkan pelanggaran maksim.

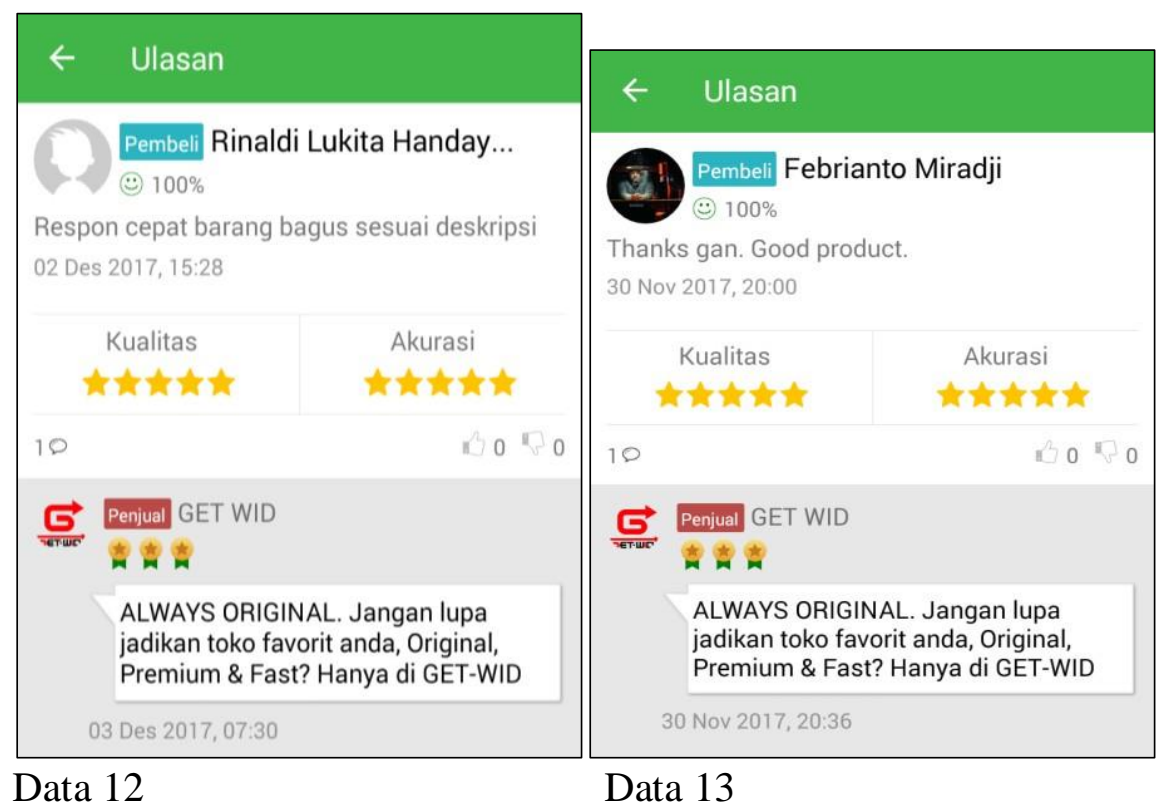

Penjual pada data 12 dan 13 menanggapi ulasan dengan melanggar dua maksim pada prinsip kerja sama, yakni maksim relevansi dan maksim kuantitas. Tuturan "ALWAYS ORIGINAL. Jangan lupa jadikan toko favorit anda. Original, Premium \& Fast? Hanya di HET-WID" tidak gayut dengan ulasan pembeli. Tanggapan penjual juga berlebihan. Selain itu penjual juga melanggar prinsip sopan santun maksim kemurahan karena ia tidak menyampaikan terima kasih atas ulasan positif yang disampaikan penjual. Jika pembeli menerapkan prinsip kerja sama dan prinsip sopan santun harusnya ia menjawab dengan tuturan "Terima kasih, jika berkenan silakan memfavoritkan lapak kami”.

\subsection{Prinsip Kerja Sama dan Prinsip Sopan Santun pada Ulasan Negatif}

Ulasan negatif adalah ulasan yang disampaikan dengan mengesampingkan prinsip kerja sama dan atau prinsip sopan satun karena pembeli merasa tidak puas.Ulasan negatif sangat merugikan penjual karena akan mempengaruhi minat calon pembeli sesudahnya. Penjual tidak dapat mengubah ulasan negatif yang telah diberikan, maka strategi berkomunikasi sangat penting dalam menanggapinya.Harus dipilih kalimat yang paling tepat agar menguntungkan dari 
berbagai sisi, atau setidaknya dapat mengurangi kesan negatif. Tanggapan penjual atas ulasan negatif harus cermat karena penjualhanya memiliki satu kali kesempatan untuk menjawab. Selain itu jawaban penjual akan dibaca oleh publik. Berikut adalah data ulasan negatif.

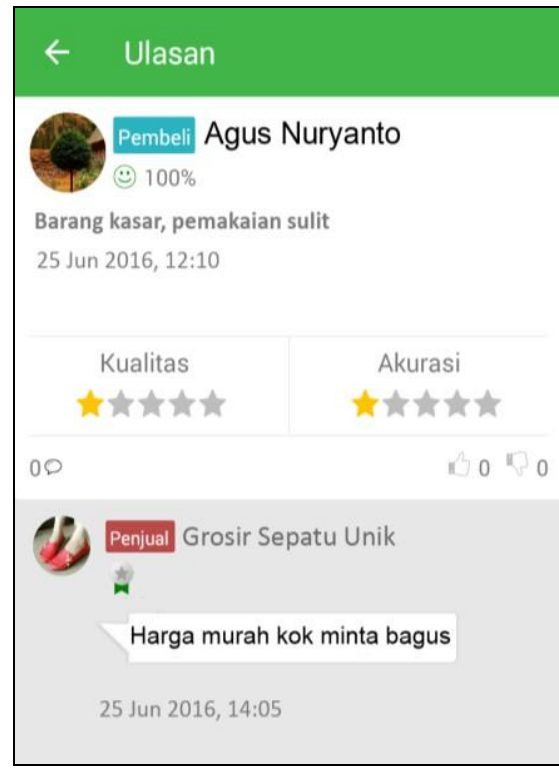

Data 12

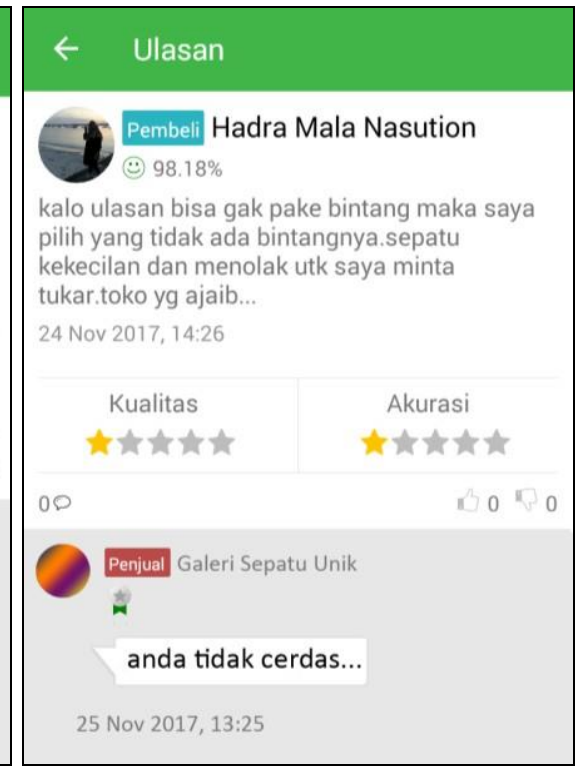

Data 13

Pembeli pada data 12 menyampaikan ulasan negatif dengan melanggar prinsip sopan santun. Tuturan "Barang kasar, pemakaian sulit" dan diikuti rating satu bintang menandakan bahwa pembeli sangat kecewa dan menginformasikan bahwa barang dan layanan yang ia terima sangat buruk. Kekecewaan tersebut yang melatari pelanggaran prinsip sopan santun maksim kemurahan dan maksim kebijaksanaan. Pembeli tidak menggunakan simbol-simbol penghormatan seperti "maaf" sebagai salah satu permenuhan maksim kemurahan. Pembeli juga telah mengabaikan dampak kerugian yang akan diterima penjual. Brown dan Levinson (dalam Chaer, 2010) menyebut sikap bahasa yang demikian sebagai muka negatif, yaitu sikap bahasa yang dengan sengaja merusak citra lawan tutur. Bisa diduga bahwa implikatur di balik tuturan tersebut adalah keinginan untuk tidak melanjutkan atau tidak mengulang kerja sama.

Penjual pada data 12 juga melakukan pelanggaran prinsip sopan santun maksim kemurahan, maksim kebijaksanaan, dan maksim kesimpatian.Tuturan "Harga murah kok minta bagus" menandakan bahwa penjual telah meniadakan penghormatan pada pembeli.Jika ia berniat memenuhi maksim kemurahan alternatif jawaban yang bisa dia sampaikan misalnya "Mohon maaf. Yang agan order adalah barang KW yang memang tak sebagus barang ori.Untuk yang ori silakan cek di lapak kami juga".Tuturan itu menandakan bahwa penjual tidak beritikat memenuhi maksim kebijaksanaan yaitu meminimalkan kerugian pihak pembeli. Jika ia berusaha memenuhi maksim kebijaksanaan seharusnya ia menawar solusi dengan tuturan misalnya "Mohon maaf, kami menyediakan berbagai variasi harga sesuai kualitas, Silakan inbox kami untuk alternatif retur". Maksim kesimpatian dapat dipenuhi apabila penjual menyampaikan rasa empati 
atas kekecewaan pembeli misal dengan tuturan "Kami turut menyesal atas ketidaknyamanan ini.Mohon bersedia inbox untuk mendiskusikan prosedur retur".

Penjual maupun pembeli pada peristiwa tuturan data 12 saling menyampaikan tuturan yang mengancam muka/muka negatif yang berimplikasi ketidakcocokan atau itikat untuk menghentikan atau tidak mengulang kerja sama. Khusus penjual, akan menerima dampak berupa citra buruk yang beresiko kehilangan pelanggan dan dihindari oleh calon pembeli, apalagi reputasi penjual tergolong rendah ditandai dengan satu pin. Analisis ini juga relevan dengan fenomena pada data 13 .

Tanggapan pembeli terhadap ulasan negatif sering hanya menjaga prinsip sopan santun, tanpa menjaga prinsip kerja sama. Berikut data data dari fenomena tersebut.

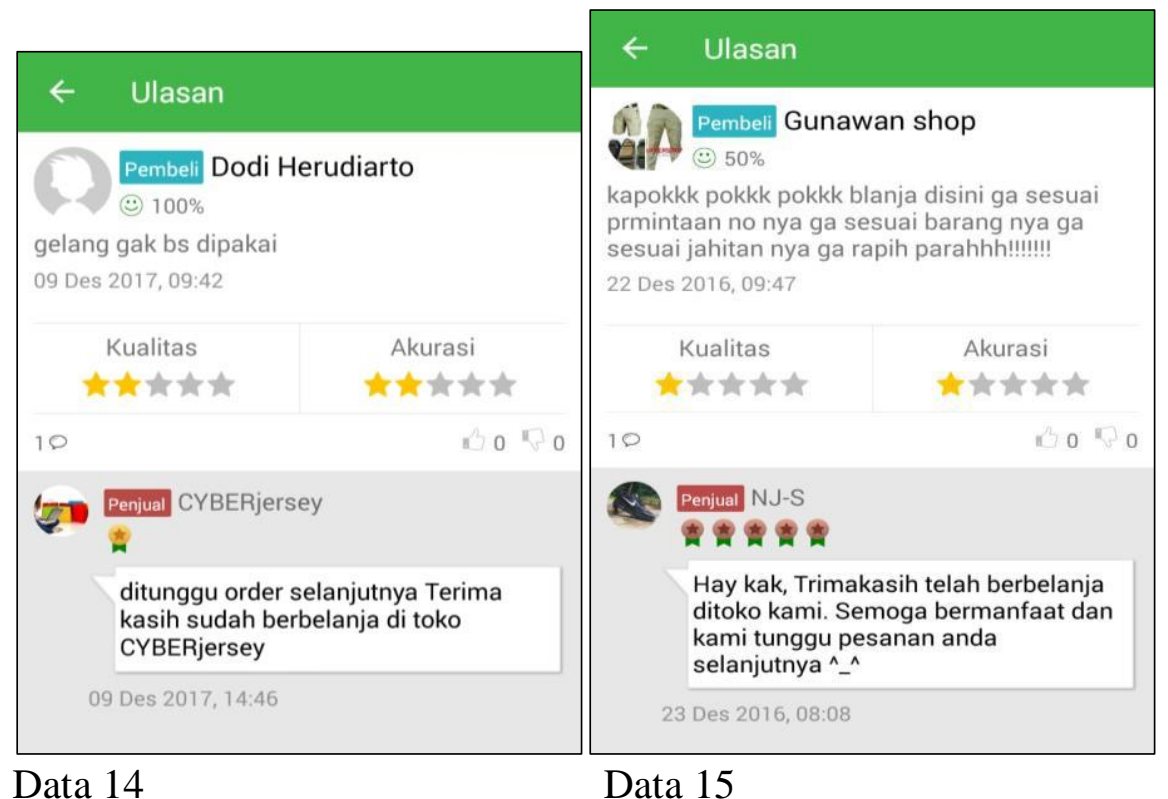

Pembeli pada data 14 dan data 15 menyampaikan kekecewaan diikuti dengan rating buruk. Pembeli pada data 14 melanggar maksim kuantitas karena ia tidak menjelaskan mengapa "gelang gak bs dipakai". Berbeda dengan pembeli pada data 14, pembeli pada data 15 lebih rinci menjelaskan apa saja yang menjadi alasan ia memberi nilai buruk. Ulasan pembeli di data 14 dan 15 sama-sama mengancam muka/muka negatif karena mengandung implikatur menjatuhkan reputasi penjual. Implikatur lain yang terkandung dalam tuturan pembeli adalah tidak ingin mengulang transaksi. Pada data 15 implikatur ditandai dengan tuturan "kapokkk pokkk pokk...".

Penjual pada data 14 dan 15 menanggapi ulasan negatif dengan hanya menonjolkan prinsip sopan satun, tanpa memperhatikan prinsip kerja sama. Tuturan "ditunggu order selanjutnya Terima kasih sudah belanja di toko CYBERjersey" melanggar prinsip kerja sama maksim relevansi karena tidak relevan dengan ulasan pembeli. Pelanggaran yang sama juga dilakukan oleh penjual pada data 15 . Walaupun mengutamakan prinsip sopan santun, sebagaimana tampak pada penggunaan tuturan "terima kasih", tanggapan penjual 
pada data 14 dan 15 tetap beresiko menimbulkan citra negatif karena terkesan tidak mengindahkan keluhan pembeli. Berikut data dari penjual yang sama dengan data 15 tetapi dengan tanggapan yang lebih memperhatikan prinsip kerja sama dan prinsip sopan santun.

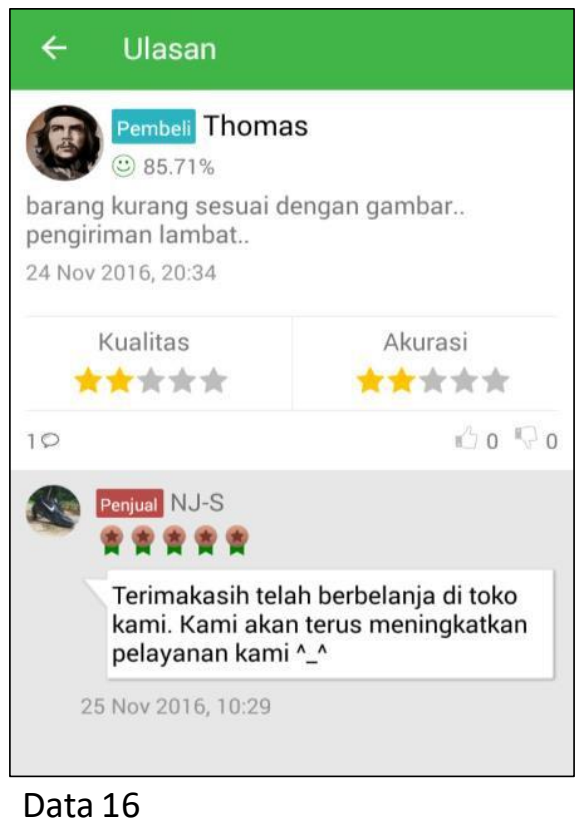

Tuturan "Terimakasih telah berbelanja di toko kami. Kami akan terus meningkatkan pelayanan ${ }^{\wedge}{ }^{\wedge}$ " menandakan bahwa penjual pemperhatikan prinsip kerja sama dan prinsip sopan santun. Penggunaan tuturan "Terimakasih" merupakan bukti pemenuhan maksim kemurahan.Penggunaan tuturan " Kami akan terus meningkatkan pelayanan kami" selain penerapan prinsip sopan santun maksim penerimaan merupakan bukti bahwa penjual berusaha memenuhi prinsip kerja sama maksim relevansi. Tanggapan demikian lebih aman untuk menjaga citra positif penjual. Implikatur yang mungkin dapat ditangkap oleh pembeli maupun calon pembeli adalah penjual adalah pribadi yang sabar dan suka menerima kritrik. Walaupun pembeli menampakkan sikap mengancam muka/muka negatif, penjual tetap menjaga muka/bermuka positif.

Terhadap ulasan negatif pembeli juga dapat menanggapi dengan memperhatikan prinsip kerja sama, tanpa memperhatikan prinsip sopan santun. Berikut adalah data yang memperlihatkan fenomena tersebut. 


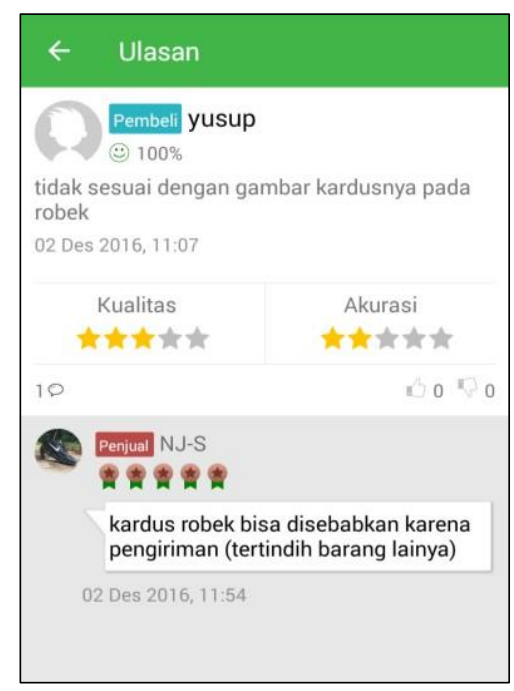

\section{Data 17}

Tanggapan pembeli pada data 17 memenuhi maksim kuantitas, kualitas, relevansi, dan maksim pelaksanaan.Tuturan "kardus robek bisa disebabkan karena pengiriman (tertindik barang lainnya)" sangat relevan dengan keluhan yang disampaikan oleh pembeli.Tanggapan tersebut disampaikan dengan lugas, simpel dan logis.Tanggapan demikian mungkin tidak dapat mengurangi kekecewaan pembeli, tetapi memberi kesan bahwa penjual tidak bersalah dalam kasus ini.Meskipun pembeli menampakkan mengancam muka/muka negatif, penjual menanggapi dengan sikap netral. Dengan demikian, penjual memberi kesan positif yang berpeluan mendapatkan simpati dari calon pembeli yang membaca. Tentu peluang akan lebih besar apabila penjual menambahkan "terima kasih" seperti tanggapan penjual pada data 16 .

Tanggapan atas ulasan negatif yang disampaikan dengan muka negatif masih mungkin berpeluang menyelamatkan muka (menjaga citra baik) apabila disampaikan dengan memenuhi maksim kualitas, kuantitas, dan relevansi. Data berikut memperlihatkan fenomena tersebut.

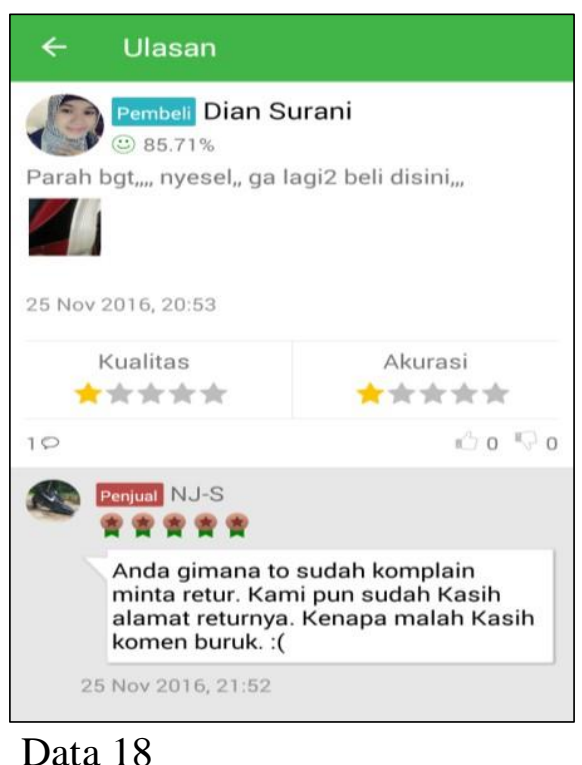


Pembeli pada data 18 menyampaikan keluhan dengan kosa kata yang mengancam muka. Tuturan "Parah bgt... nyesel, ga lagi2 beli disini..." jelas melanggar prinsip sopan santun dari semua maksim. Pembeli menanggapi dengan mengesankan mengancam muka juga. Tuturan "Anda gimana to sudah komplain minta retur. Kami pun sudah Kasih alamat returnya. Kenapa malah kasih komen buruk. :(“ mengandung implikatur "penjual telah berusaha mengatasi masalah, tetapi pembeli tidak beritikat baik". Implikatur ini mendukung kesan bahwa penjual telah memenuhi prinsip kerjasama pada tuturannya. Tuturan tanggapan penjual memenuhi maksim kualitas karena fasilitas komplain memang disediakan dan sangat mudah untuk digunakan oleh pembeli. Maksim kuantitas dipenuhi oleh penjual karena informasi cukup jelas. Tuturan penjual juga memenuhi maksim relevansi karena tidak menyimpang dari persoalan yang dilontarkan oleh pembeli.

Di laman ulasan juga terdapat ulasan negatif yang ditanggapi dengan memperhatikan maksim kualitas dan maksim kesimpatian. Berikut data tentang fenomena tersebut.

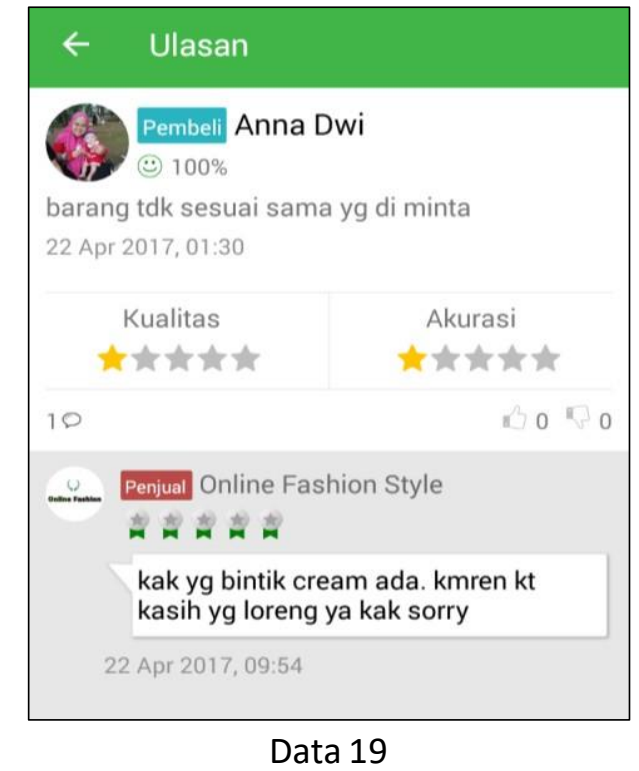

Tanggapan penjual pada data 19 mengutamakan prinsip kerja sama dan prinsip sopan santun. Tuturan "kak yg bintik cream ada.kmaren kt kasih yg loreng ya kak sori" membuktikan bahwa penjual ingin bersikap jujur dan mengakui kesalahan sebagai pemenuhan atas maksim kualitas. Kata "sorry" di akhir tuturan merupakan pemenuhan prinsip sopan santun maksim kesimpatian. Pembeli turut menyesal atas kekeliruan yang ia lakukan. Komunikasi yang demikian memungkinkan untuk dibaca oleh pembeli maupun calon pembeli sebagai tanggapan yang mengandung implikatur ajakan untuk menyelesaikan masalah melalui komiunikasi di inbox.

Mirip dengan tanggapan ulasan positif pada data 6 dan 7, terhadap ulasan negatif juga terdapat penghentian komunikasi satu pihak yang ditandai dengan ketiadaan respon oleh penjual. Data 20 dan 21 menunjukkan fenomena tersebut. 


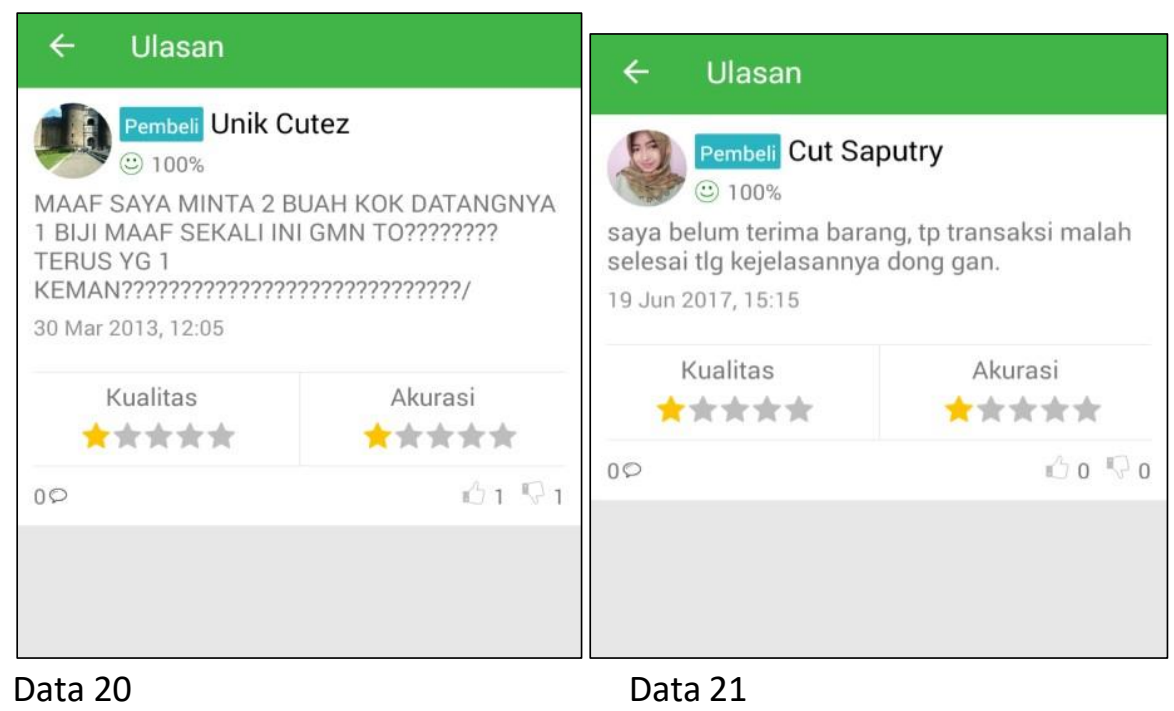

Pembeli pada data 20 dan 21 menyampaikan komplain dengan terus terang. Ulasan negatif jelas mengancam muka (citra penjual). Tidak menjawab berarti penjual telah mengesankan pada publik bahwa ia tidak bertanggung jawab. Penjual telah melanggar prinsip kerja sama dan sopan santun. Terhadap ulasan yang telah mengesampingkan prinsip sopan santun begini sebenarnya penjual masih berpeluang menyelamatkan citranya misal dengan meminta maaf dan menjelaskan seperti yang dilakukan oleh penjual pada data 19. Atau mengajak pembeli berdiskusi di inbox untuk menyelesaikan masalah. Tentu apabila penjual pada data 20 dan 21 ini mau mempelajari cara berbahasa penjual dengan reputasi lima pin seperti penjual pada data 19.

\section{Simpulan}

Ulasan positif selalu memperhatikan prinsip kerja sama dan atau prinsip sopan santun walaupun mengandung kritik. Ulasan yang memperhatikan prinsipprinsip pragmatik umumnya mendapat respon yang memperhatikan prinsipprinsip pragmatik pula. Penjual yang mampu menerapkan prinsip pragmatik umumnya dapat berkembang ditandai dengan pin reputasinya. Sebaliknya, penjual yang tidak menerapkan prinsip pragmatik umumnya tidak dapat berkembang, ditandai dengan pin reputasi yang sedikit.

Ulasan negatif adalah tantangan yang paling berat bagi penjual untuk menerapkan prinsip pragmatik dalam tuturan tanggapan. Beberapa data menunjukkan bahwa penjual cenderung terpengaruh untuk membalas ulasan negatif dengan tanggapan negatif. Para penjual dengan reputasi baik (bintang perak) umumnya dapat menerapan prinsip kerja sama dan atau prinsip sopan santun dalam menanggapi ulasan negatif. Analisis penelitian ini membuktikan bahwa terdapat korelasi antara kemampuan menerapkan prinsip-prinsip pragmatik dengan kesuksesan bisnis daring.

Penelitian terhadap data-data menghasilkan rekomendasi-rekomendasi sebagai berikut.Tanggapan yang baik atas ulasan positif sebaiknya mengandung hal-hal berikut: (1) penghargaan kepada pembeli atas apresiasi positif yang telah 
diberikan; (2) sikap religius berupa rasa syukur atas kesuksesan transaksi; (3) harapan semoga barang awet; (4) harapan agar pembeli berbelanja kembali atau memfavoritkan lapaknya. Tanggapan atas ulasan negatif sebaiknya mengandung hal-hal berikut: (1) penghargaan kepada pembeli yang telah mengapresaiasi walaupun menganggap buruk barang atau layan yang telah diberikan; (2) pemberian wawasan kepada publik bahwa penilaian negatif itu tak sepenuhnya benar; (3) pemberian kesan pada publik bahwa penjual tidak anti kritik; (4) pelurusan pandangan pembeli apabila pembeli salah menilai.

\section{Daftar Pustaka}

Arikunto, Suharsimi.2006. Prosedur Penelitian: Jakarta:Rineka Cipta.

Chaer, Abdul.2010.Kesantunan Berbahasa. Jakarta:PT Rineka Cipta.

Gunawan, Asim. 2007. Pragmatik Teori dan Kajian Nusantara. Jakarta: Universitas Atma

Leech, Geoffrey. 1983. Principles of Pragmatic. Terj.M.D.D.Oka Prinsip-Prinsip Pragmatik. Jakarta: Universitas Indonesia. London:Longman.

Levinson, C. Stephen. 1997. Pragmatics. Great Britain: Cambridge University Press

Mahsun.2005. Metode Penelitian Bahasa. Jakarta:PT Raja Grafindo Persada.

Rustono.1999.Pokok-Pokok Pragmatik. Semarang.IKIP.Semarang Press.

Sudaryanto. 1993. Metode dan Aneka Teknik Analisis Bahasa Pengantar Penelitian Wahana Kebudayaan dan Linguistik. Yogyakarta:Duta Wahana University Press

Tarigan, Henry Guntur.1990. Pengajaran Pragmatik.Bandung:Angkasa. 